\title{
Mekanisme Penyelesaian Sengketa Pajak dalam Sistem Peradilan di Indonesia
}

\author{
Nabitatus Sa'adah \\ Fakultas Hukum, Universitas Diponegoro \\ Email: n4b1t4tuz@yahoo.com
}

\begin{abstract}
This study aims to determine the mechanism of tax dispute resolution in the justice system in Indonesia, specifically knowing the mechanism of tax dispute resolution and the characteristics of tax dispute resolution if juxtaposed with the justice system in Indonesia. The research method used is normative legal research that uses the laws and regulations (positive law). The results show that tax disputes in Indonesia, especially disputes over tax assessment letters, can be resolved through dispute resolution efforts in the executive domain, namely objection efforts which are one form of dispute resolution through administrative efforts, and dispute resolution through pure judicial institutions. namely the Tax Court in the form of appeal lawsuits and claims. Whereas the Tax Dispute Resolution Mechanism when viewed with the judicial system in general shows that there is a separate specificity from other dispute resolution systems in the judiciary.
\end{abstract}

Keywords: Tax dispute, Tax Court, Judicial System

\begin{abstract}
Abstrak
Penelitian ini bertujuan untuk mengetahui mekanisme penyelesaian sengketa pajak dalam sistem peradilan di Indonesia, secara khusus mengetahui mekanisme penyelesaian sengketa pajak dan karakteristik penyelesaian sengketa pajak jika disandingkan dengan sitem peradilan di Indonesia. Metode penelitian yang digunakan dalah penelitian hukum normatif yang menggunakan pendakatan peraturan perundang undangan (hukum positif). Hasil penelitian menjukan bahwa sengketa pajak di Indonesia, khususnya sengketa atas Surat Ketetapan Pajak dapat diselesaikan melalui upaya penyelesaian sengketa dalam ranahnya eksekutif terlebih dahulu yaitu upaya keberatan yang merupakan salah satu bentuk penyelesaian sengketa melalui upaya administratif, dan penyelesaian sengketa melalui lembaga peradilan murni (yudikatif) yaitu Pengadilan Pajak yang berupa upaya hukum banding dan gugatan. Sedangkan Mekanisme Penyelesaian sengketa pajak apabila dilihat dengan sistem peradilan secara umum terlihat bahwa ada suatu kekhususan tersendiri yang berbeda dengan sistem penyelesaian sengketa pada peradilan yang lainnya.
\end{abstract}

Kata Kunci: Sengekta pajak, Pengadilan Pajak, Sistem Peradilan, 


\section{A. Pendahuluan}

Tugas negara dalam rangka memberikan kesejahteraan terhadap rakyat tentunya membutuhkan dana yang tidak sedikit.Salah satu sumber pembiayaan yang diandalkan negara saat ini adalah dari sektor mandiri yang berasal dari pungutan wajib masyarakat yang berupa pajak. Sadar akan pentingnya penerimaan pajak bagi penerimaan negara disakipi pemerintah dengan melakukan beberapa kebijakan pemerintah sebagai upaya meningkatkan penerimaan negara dari sektor pajak. Upaya tersebut antaralain melalui intensifikasi pajak maupun ekstensifikasi pajak. Pembaharuan sistem perpajakan (tax reform) juga merupakan satu langkah yang sangat penting sebagai langkah pengoptimalan pajak sebagai penerimaan negara.

Upaya tax reform dilakukan dengan cara penyederhanaan jenis pajak, tarif, penyederhanaan pembenahan prosedur pemungutan pajak, jaminan kepastian hukum serta pembenahan aparatur pajak ${ }^{1}$. Perubahan sistem pemungutuan pajak yang pada awalnya mendasarkan pada keaktifan fiskus (official assessment) dianggap tidak efektif dalam upaya pengoptimalan penerimaan pajak sehingga perlu dilakukan perubahan dengan mendasarkan keaktifan dari wajib pajak untuk melakukan kewajiban perpajakan (self assessment). Dalam sistem ini (self assessment system) pemerintah tidak perlu aktif mencari wajib pajak, tetapi mengandal instrument undang-undang untuk mencari wajib pajak.

Berdasarkan sistem self assessment ini orang atau badan yang memenuhi kriteria sebagai wajib pajak harus sadar diri untuk mendaftar, melapor dan membayar kewajiban perpajakannya sendiri tanpa menunggu Surat Ketetapan Pajak (SKP) yang dikeluarkan oleh fiskus hal demikian diatur dalam Pasal 2 ayat ( 1 ) UU No. 28 tahun 2007 sebagaimana diubah terakhir dengan UU No 16 tahun 2009 tentang Ketentuan Umum Tata Cara Perpajakan. Kesadaran, kedisiplinan dan kejujuran wajib pajak merupakan hal yang sangat penting dalam pelaksanaan self assessment system ini ${ }^{2}$. Self assessment system agar sesuai dengan tujuan awal yaitu sebagai salah satu upaya mengoptimalkan penerimaan pajak, sudah sewajarnya diperlukan pengawasan juga dari pemerintah. Undang-undang KUP memberi kewenangan pemerintah melakukan pengawasan dalam bentuk pemeriksaan pajak hal demikian diatur dalam ( Pasal 29 ayat ( 1 ) UU. No. 28 tahun 2007 ). Berdasarkan hasil pemeriksaan apabila terdapat perbedaan perhitungan dengan apa yang laporkan wajib pajak dalam Surat Pemberitahuannya (SPT) nya maka

\footnotetext{
${ }^{1}$ Rochmat Soemitro, 1992, Pengantar Singkat Hukum Pajak,Eresco, Bandung,hlm.28

${ }^{2}$ Rochmat Soemitro, , 1991,Asas Dan Dasar Perpajakan Jilid 2, Eresco, Bandung, hlm 14.
} 
fiskus berwenang mengeluarkan Surat Ketetapan Pajak. Hal demikian sebagaimana yang diatur dalam Pasal 13, 15,17. 17 A UU KUP.

Faktanya seringkali terjadi perbedaan perhitungan antara wajib pajak dan fiskus. Wajib pajak kadangkala tidak menyetujui besarnya jumlah pajak besarnya pajak yang dihitung oleh fiskus yang tertuang dalam Surat Ketetapan Pajak. Perbedaan perhitungan antara fiskus dan wajib pajak inilah yang merupakan salah satu sebab timbulnya suatu sengketa pajak. Pengertian sengketa pajak menurut Pasal 1 ayat ( 5 ) Undang-undang Nomor 14 tahun 2002 tentang Pengadilan Pajak ( selanjutnya ditulis UU No.14 tahun 2002 ), yaitu sengketa yang timbul dalam bidang perpajakan antara wajib pajak dengan pejabat yang berwenang sebagai akibat dikeluarkannya keputusan yang dapat diajukan banding atau gugatan kepada Pengadilan Pajak berdasarkan peraturan perundangundangan perpajakan, termasuk gugatan atas pelaksanaan penagihan berdasarkan undangundang penagihan pajak dengan Surat Paksa.

Berdasakan definisi di atas, sengketa pajak timbul apabila : 1. Akibat dikeluarkannya keputusan yang dapat diajukan banding. Keputusan yang dapat diajukan banding adalah keputusan atas keberatan yang diajukan wajib pajak sebagai akibat dikeluarkannya SKPKB, SKPKBT, SKPLB, SKPN, dan keberatan atas pemotongan atau pemungutan oleh pihak ketiga berdasarkan perundang-undangan perpajakan. 2. Adanya hal-hal yang dapat diajukannya gugatan, yaitu: a.Pelaksanaan Surat Paksa, Surat Perintah Melaksanakan Penyitaan, atau Pengumuman Lelang; b.Keputusan yang berkaitan dengan pelaksanaan keputusan perpajakan, selain keputusan atas keberatan c.Keputusan pembetulan yang berkaitan dengan Surat Tagihan Pajak; d.Keputusan tentang pengurangan dan penghapusan sanksi administrasi yang berkaitan dengan Surat Tagihan Pajak.

Dalam kerangka negara hukum,setiap timbulnya suatu sengketa ,negara wajib menyediakan akses atau jalur penyelesaian sengketa termasuk didalamnya sengketa pajak. Sesuai sifat dan karakteristik pajak sebagai sumber utama pemasukan negara, pengaturan pemungutan pajak mempunyai kekhususan yang terlihat dalam berbagai ketentuan. Hal demikian juga terlihat dalam ketentuan yang mengatur tentang penyelesaian sengketa pajak. Mekanisme penyelesaian sengketa pajak menarik untuk dibahas jika disandingkan dengan penyelenggaraan sistem peradilan secara umum. Berdasarkan latar belakang di atas maka maka yang menjadi permasalahan dalam penelitian ini adalah sebagai berikut : Bagaimana mekanisme penyelesaian sengketa pajak di Indonesia? Dan Bagaimana 
karakteristik penyelesaian sengketa pajak jika disandingkan dengan sitem peradilan di Indonesia?

\section{Pembahasan}

\section{Sengketa Pajak dan Mekanisme Penyelesaiannya}

Penyelesaian sengketa pajak memiliki spesifikasi penyelesaian sengketa sendiri dibanding penyelesaian sengketa yang lain. Hal demikian berkaitan dengan karektiristik pajak sebagai sumber penerimaan negara. Penyelesaian sengketa pajak mengenal ada dua mekanisme yaitu penyelesaian sengketa melalui upaya administratif yaitu melalui lembaga keberatan dan melalui lembaga yudikasi yaitu Pengadilan Pajak.

Upaya administratif sering disebut sebagai peradilan administrasi tidak murni. Peradilan administrasi tak murni, adalah semua peradilan yang tidak sepenuhnya memenuhi syarat-syarat peradilan administrasi murni, misalnya karena tidak nyata terdapat suatu perselisihan, atau karena yang mengadakan peradilan termasuk dalam atau merupakan bagian dari salah satu pihak ${ }^{3}$. Salah satu upaya administratif yang dipakai dalam penyelesaian sengketa upaya keberatan.

Apabila wajib pajak mempunyai sengketa atas Surat Ketetapan Pajak yang dapat berupa, Surat Ketetapan Pajak Kurang Bayar (SKPKB), Surat Ketetapan Pajak Kurang Bayar Tambahan (SKPKBT), Surat Ketetapan Pajak Lebih Bayar (SKPLB), Surat Ketetapan Pajak Nihil (SKPN), atau sengketa atas pemotongan dan pemungutan pihak ketiga maka wajib pajak dapat menyelesaikan sengketa pajaknya melalui upaya keberatan.

Dalam pengajuan keberatan wajib pajak harus mengajukan surat keberatan. Surat keberatan adalah surat yang diajukan oleh wajib pajak, yang harus memenuhi syarat-syarat tertentu. Surat keberatan tersebut dapat berupa surat keberatan atas Surat Ketetapan Pajak Kurang Bayar, Surat Ketetapan Pajak Kurang Bayar Tambahan, Surat Ketetapan Pajak Lebih Bayar, Surat Ketetapan Pajak Nihil dan terhadap pemotongan atau pemungutan oleh pihak ketiga berdasarkan ketentuan peraturan perundang-undangan perpajakan. Surat Keberatan tersebut diajukan kepada pejabat yang berwenang mengeluarkan Surat Ketetapan Pajak. Keberatan diajukan secara tertulis dalam bahasa Indonesia dengan mengemukakan jumlah pajak yang terutang atau jumlah pajak yang dipotong atau dipungut atau jumlah rugi menurut perhitungan wajib pajak dengan disertai alasan-alasan yang jelas.

${ }^{3}$ Rochmat Sumitro,Asas Dan Dasar Perpajakan jilid 3.Eresco,Bandung,1997 hlm.51. 
Berbicara mengenai dasar atau alasan pengajuan keberatan, undang-undang memberi penjelasan sebagaimana yang tercantum dalam Penjelasan Pasal 25 ayat (1) Undang-undang Nomor 28 tahun 2007, yang berbunyi sebagai berikut :

“Apabila Wajib Pajak berpendapat bahwa jumlah rugi, jumlah pajak dan pemotongan atau pemungutan tidak sebagaimana mestinya, maka wajib pajak dapat mengajukan keberatan hanya kepada Direktur Jendral Pajak".

Keberatan dapat diajukan terhadap materi atau isi dari ketetapan pajak, yaitu jumlah rugi berdasarkan ketentuan undang-undang perpajakan, jumlah besarnya pajak, pemotongan atau pemungutan pajak.

Agar wajib pajak dapat menyusun keberatan dengan alasan-alasan yang kuat, wajib pajak diberi hak untuk meminta dasar-dasar pengenaan, pemotongan atau pemungutan pajak yang telah ditetapkan.

Batas waktu pengajuan surat keberatan ditentukan dalam jangka waktu 3 ( tiga ) bulan sejak diterbitkannya Surat Ketetapan Pajak atau sejak tanggal pemotongan atau pemungutan oleh pihak ketiga yang diberi wewenang oleh ketentuan peraturan perundangundangan perpajakan untuk memotong atau memungut pajak. Pemberian batas waktu tiga bulan ini dimaksudkan untuk memberi waktu yang cukup bagi wajib pajak untuk mempersiapkan surat keberatan beserta alasannya. Batas waktu tiga bulan ini masih bisa dipertimbangkan untuk diperpanjang apabila wajib pajak mampu membuktikan bahwa keterlambatan pengajuan surat keberatan tersebut disebabkan karena keadaan diluar kekuasaan wajib pajak ( force majeure ).

Setelah surat keberatan diajukan kepada pejabat yang berwenang, wajib pajak berhak untuk menerima tanda bukti penerimaan surat keberatan.Tanda penerimaan surat yang diberikan oleh pejabat yang berwenang, secara langsung atau lewat kantor pos berfungsi sebagai tanda terima surat keberatan.Tanda bukti / resi penerimaan surat keberatan tersebut, dapat juga berfungsi sebagai alat kontrol bagi wajib pajak untuk mengetahui sampai kapan batas waktu dua belas bulan itu berakhir, hal ini mengingat bahwa dalam waktu paling lama dua belas bulan sejak tanggal surat keberatan diterima, Direktur Jendral Pajak ( untuk Pajak Pusat) atau Kepala Daerah ( untuk Pajak Daerah ), harus memberi keputusan atas keberatan yang diajukan oleh wajib pajak. Dalam rangka memberi kepastian kepada wajib pajak, apabila dalam jangka waktu dua belas ini telah lewat, pejabat yang berwenang tidak memberi suatu keputusan, maka keberatan yang diajukan oleh wajib pajak dianggap diterima. 
Pembuktian dalam surat keberatan hanya diatur dalam Pasal 26 ayat ( 4 ) Undangundang No. 28 tahun 2007, yang menyatakan bahwa ; “Dalam hal wajib pajak mengajukan surat keberatan atas ketetapan pajak yang ditentukan dalam Pasal 13 ayat ( 1 ) huruf $b$ dan $d$, wajib pajak yang bersangkutan harus dapat membuktikan ketidak benaran ketetapan tersebut".

Berdasarkan bunyi pasal tersebut, dalam hal wajib pajak mengajukan keberatan atas SKP yang ditetapkan secara jabatan, maka wajib pajaklah yang harus membuktikan ketidak benaran ketetapan pajak yang dikenakan. SKP yang diterbitkan secara jabatan adalah SKP yang diterbitkan Direktur Jendral Pajak terhadap kasus-kasus tertentu yaitu terhadap wajib pajak yang nyata-nyata atau berdasarkan hasil pemeriksaan tidak memenuhi kewajiban formal dan / atau kewajiban materiil.

Wajib pajak dalam rangka membuktikan kebenaran Surat Pemberitahuannya (SPT) dapat mengajukan beberapa alat bukti. Undang-undang tidak mengatur secara tegas mengenai alat bukti apa yang harus ditunjukkan wajib pajak. Dalam praktek alat bukti yang sering ditunjukkan wajib pajak adalah alat bukti tulisan antara lain pembukuan yang dibuat oleh wajib pajak.

Penyelesaian sengketa pajak di muka lembaga keberatan, sangatlah berbeda dengan penyelesaian sengketa di muka pengadilan. Surat keberatan diputuskan oleh hakim doleansi ( pejabat pajak yang diberi tugas untuk memutus surat keberatan), tanpa mengadakan sidang seperti yang dilakukan di pengadilan ${ }^{4}$.

Pemberian keputusan atas surat keberatan didasarkan atas data yang diajukan oleh wajib pajak dan data yang ada pada fiskus. Pemutusan sengketa dilakukan secara sepihak oleh "hakim" tunggal ( pejabat pajak ) yang notabene merupakan salah satu pihak yang berperkara ${ }^{5}$.Keputusan atas surat keberatan dapat berupa menerima seluruhnya atau sebagian, menolak, menambah besarnya jumlah pajak yang terutang.

Apabila surat keberatan diterima seluruhnya maka keputusan tersebut tidak perlu diberi alasan, cukup dinyatakan bahwa keberatan wajib pajak diterima. Tetapi apabila keputusan atas surat keberatan berisi menerima sebagian, menolak atau bahkan menambah besarnya jumlah pajak yang terutang maka keputusan tersebut biasanya disertai dengan alasan-alasan yang mendasarinya.

Dalam hal wajib pajak ditolak atau dikabulkan sebagian,wajib pajak dikenai sanksi administrasi berupa denda sebesar 50\% ( lima puluh persen ) dari jumlah pajak

\footnotetext{
${ }^{4}$ Rochmat Soemitro, Asas Dan Dasar...jilid 2, Op.Cit., hlm.174

${ }^{5}$ Ibid., hlm. 175
} 
berdasarkan keputusan keberatan dikurangi dengan pajak yang telah dibayar sebelum mengajukan keberatan.

Penyelesaian sengketa pajak selain dapat diselesaikan melalui lembaga tidak murni yaitu lewat lembaga keberatan, juga dapat di selesaikan oleh lembaga pengadilan pajak murni ( yudikatif ). Rochmat Soemitro menjelaskan ${ }^{6}$, yang dimaksud peradilan administrasi murni adalah peradilan administrasi yang memenuhi syarat-syarat yang menyerupai peradilan yang dilakukan oleh pengadilan.Ciri khas suatu peradilan administrasi murni adalah adanya hubungan segitiga antara para pihak dan badan atau pejabat yang mengadili. Badan atau pejabat yang mengadili merupakan badan atau pejabat tertentu dan terpisah. " Tertentu " artinya badan atau pejabat tersebut ditentukan oleh Undang-undang atau oleh peraturan lain yang setingkat."Terpisah", artinya badan atau pejabat yang melakukan pengadilan tidak merupakan salah satu pihak atau termasuk salah satu pihak maupun di bawah pengaruh salah satu pihak, sehingga badan atau pejabat yang mengadili perkara itu berada di atas para pihak.

Ada dua upaya hukum dalam penyelesaian sengketa pajak yang dapat ditempuh melalui Pengadilan Pajak yaitu banding dan gugatan.

Upaya Banding dapat dilakukan, apabila wajib pajak tidak dapat menerima keputusan keberatan yang dikeluarkan oleh pejabat yang berwenang. Pasal 1 ayat (6) UU. No. 14 Tahun 2002 memberi definisi mengenai banding sebagai berikut;

" Banding adalah upaya hukum yang dilakukan oleh wajib pajak atau penanggung pajak terhadap suatu keputusan yang dapat diajukan banding, berdasarkan peraturan perundang-undangan perpajakan yang berlaku “.

Undang-undang memberi beberapa syarat yang harus dipenuhi wajib pajak dalam mengajukan surat banding. Persyaratan pengajuan banding diatur dalam Pasal 27 Undang-undang Nomor 28 tahun 2007 Jo. UU No.16 tahun 2009. Syarat-syarat tersebut adalah sebagai berikut:

1.Permohonan banding harus diajukan secara tertulis dalam Bahasa Indonesia, dan ditujukan kepada Pengadilan Pajak..

2.Tenggang waktu pengajuan banding adalah 3 ( tiga ) bulan, perhitungan ini dimulai sejak tanggal diterima keputusan yang dibanding ( keputusan atas keberatan ), sampai dengan tanggal surat banding dikirim oleh pemohon banding.Apabila surat permohonan banding diajukan lewat dari jangka waktu tiga

${ }^{6}$ Ibid., hlm. 50. 
bulan, permohonan tersebut akan ditolak kecuali apabila pemohon banding dapat memberi alasan bahwa jangka waktu tersebut tidak dapat dipenuhi karena keadaan diluar kekuasaannya ( force majeur ). Berdasarkan alasan tersebut, jangka waktu tersebut dapat dipertimbangkan oleh majelis atau hakim tunggal.

3.Terhadap satu keputusan diajukan satu surat banding.

4.Banding diajukan dengan disertai alasan-alasan yang jelas dan dicantumkan tanggal terima surat keputusan yang di banding.

5.Surat banding harus dilampiri salinan keputusan yang dibanding.

6.Dalam hal permohonan banding ditolak atau dikabulkan sebagian ,wajib pajak dikenai sanksi administrasi berupa denda sebesar $100 \%$ ( seratus persen ) dari jumlah pajak berdasarkan putusan banding dikurangi pembayaran pajak yang telah dibayar sebelum mengajukan keberatan.

Selain upaya hukum banding, jalur penyelesaian sengketa yang dapat diambil wajib pajak melalui Pengadilan Pajak adalah gugatan. Berdasarkan bunyi Pasal 1 Ayat ( 7 ) Undang-undang Nomor 14 tahun 2002, yang dimaksud Gugatan adalah upaya hukum yang dapat dilakukan oleh wajib pajak terhadap pelaksanaan penagihan pajak atau terhadap keputusan yang dapat diajukan gugatan berdasarkan peraturan perundang-undangan yang berlaku.

Gugatan harus diajukan secara tertulis dalam Bahasa Indonesia, dan diajukan hanya kepada Pengadilan Pajak. Gugatan harus disertai dengan alasan-alasan yang jelas, mencantumkan tanggal diterimanya pelaksanaan penagihan atau keputusan yang digugat dan dilampiri salinan dokumen yang digugat.

Jangka waktu pengajuan gugatan dibedakan menjadi dua, yaitu jangka waktu pengajuan gugatan terhadap pelaksanaan penagihan pajak, dan jangka waktu pengajuan gugatan terhadap keputusan-keputusan yang dapat diajukan gugatan. Jangka waktu pengajuan gugatan terhadap pelaksanaan penagihan pajak adalah 14 ( empat belas ) hari sejak tanggal pelaksanaan penagihan. Jangka waktu untuk mengajukan gugatan terhadap keputusan-keputusan yang dapat diajukan gugatan adalah 30 ( tiga puluh ) hari sejak tanggal diterima keputusan yang dapat digugat.

Jangka waktu sebagaimana tersebut di atas masih dapat dipertimbangkan apabila jangka waktu tersebut tidak terpenuhi karena keadaan di luar kekuasaan penggugat. Perpanjangan jangka waktu tersebut adalah 14 ( empat belas ) hari yang dihitung sejak berakhirnya keadaan di luar kekuasaan penggugat. Pengajuan gugatan 
tidak menunda atau menghalangi dilaksanakannya penagihan pajak atau kewajiban perpajakan.

Putusan Pengadilan Pajak bersifat final, upaya hukum kasasi tidak dikenal dalam penyelesaian sengketa ini. Dalam hal wajib pajak masih merasa belum puas atas keputusan Pengadilan Pajak, wajib pajak diberi kesempatan untuk melakukan upaya hukum luar biasa yaitu Peninjauan Kembali ke Mahkamah Agung ${ }^{7}$. PK hanya dapat diajukan satu kali kepada Mahkamah Agung melalui Pengadilan Pajak. Permohonan Peninjauan Kembali hanya dapat diajukan berdasarkan alasan-alasan sebagaimana yang tertuang dalam pasal 91 Undang-undang Nomor 14 Tahun 2002 :

a.Apabila putusan Pengadilan Pajak didasarkan pada suatu kebohongan atau tipu muslihat pihak lawan yang diketahui setelah perkaranya diputus atau didasarkan pada bukti-bukti yang kemudian oleh hakim pidana dinyatakan palsu;

b.Apabila terdapat bukti tertulis baru yang penting dan bersifat menentukan, yang apabila diketahui pada tahap persidangan di Pengadilan Pajak akan menghasilkan putusan yang berbeda;

c.Apabila telah dikabulkan suatu hal yang tidak dituntut atau lebih dari pada yang dituntut, kecuali yang diputus berdasarkan Pasal 80 ayat ( 1 ) huruf b dan c (putusan Pengadilan Pajak yang berupa mengabulkan sebagian atau seluruhnya, mengabulkan sebagin atau seluruhnya);

d.Apabila mengenai suatu bagian dari tuntutan belum diputus tanpa dipertimbangkan sebab-sebabnya; atau

e.Apabila terdapat suatu putusan yang nyata-nyata tidak sesuai dengan ketentuan peraturan perundang-undangan yang berlaku.

Permohonan PK tidak menangguhkan atau menghentikan pelaksanaan putusan Pengadilan Pajak.

\section{Mekanisme Penyelelesaian Sengketa Pajak Dikaitkan Dengan Sistem Peradilan Di Indonesia.}

Untuk membandingkan sistem peradilan pajak apakah sudah sesuai dengan sistem peradilan di Indonesia, maka akan peneliti uraiakan dulu mekanisme penyelesaian sengketa dalam peradilan lain yang ada diempat lingkungan peradilan yang ada yaitu,

\footnotetext{
${ }^{7}$ Pasal yang mengatur upaya Peninjauan Kembali adalah Pasal 89-93 Undang-undang Nomor 14 tahun 2002.
} 
Peradilan Umum. Peradilan Agama, Peradilan Militer dan Peradilan Tata usaha Negara.Sebagaimana kita ketahui penyelesaian sengketa melalui jalur pengadilan diselenggarakan oleh Kekuasaan Kehakiman. Hal demikian sebagaimana tersebut dalam Pasal 24 ayat ( 1 ) Undang-undang Dasar 1945, yang menyatakan bahwa,

“ Kekuasaan Kehakiman merupakan kekuasaan yang merdeka untuk menyelenggarakan peradilan guna menegakkan hukum dan keadilan ".

Lebih lanjut dalam Pasal 24 ayat ( 2 ) disebutkan, bahwa,

“ Kekuasaan Kehakiman dilakukan oleh sebuah Mahkamah Agung dan badan peradilan yang berada dibawahnya dalam lingkungan peradilan umum, lingkungan peradilan agama, lingkungan peradilan militer, lingkungan peradilan tata usaha negara, dan oleh sebuah Mahkamah Konstitusi “.

Penyelenggaraan Kekuasaan Kehakiman juga diatur Pasal 18 UU No.48 tahun 2009 tentang Kekuasaan Kehakiman ( selanjutnya disebut UU Kekuasaan kehakiman ) yang menyatakan;

“ Kekuasaan kehakiman dilakukan oleh sebuah Mahkamah Agung dan badan peradilan yang ada di bawahnya dalam lingkungan peradilan umum, lingkungan peradilan agama, lingkungan peradilan militer, lingkungan peradilan tata usaha negara, dan oleh sebuah Mahkamah Konstitusi “

Ke-empat lingkungan di bawah Mahkamah Agung ini masing-masing mempunyai lingkungan wewenang mengadili tertentu yang dibedakan menurut undangundang. Perbedaan wewenang mengadili ini apabila kita lihat dapat dibedakan menjadi dua, yaitu pertama, peradilan khusus, karena mengadili perkara tertentu atau golongan rakyat tertentu yang meliputi Peradilan Agama, Peradilan Militer, dan Peradilan Tata Usaha Negara. Kedua, peradilan umum yaitu peradilan bagi rakyat pada umumnya, baik mengenai perkara perdata, maupun perkara pidana.

Sesuai dengan Pasal 21 UU Kekuasaan Kehakiman , masing-masing badan-badan Peradilan di atas secara organisatoris, administratif dan finansial berada dibawah kekuasaan Mahkamah Agung.

Dalam menjalankan fungsinya masing-masing peradilan memerlukan beberapa peraturan untuk dijadikan sebagai suatu pedoman, hal demikian sesuai dengan salah satu ciri adanya peradilan yaitu adanya suatu aturan abstrak yang mengikat umum, maka dalam menyelesaikan suatu perkara masing-masing peradilan juga mempunyai aturan tersendiri yang dijadikan pedoman untuk menyelesaikan suatu perkara, baik aturan material maupun aturan formal. Adanya aturan hukum material dan aturan formal memang sangat penting dalam suatu peradilan. Hukum formil atau yang sering disebut 
hukum acara atau hukum proses yang mengatur penegakan hukum yang materinya ditentukan dalam hukum materiilnya ${ }^{8}$. Peradilan tanpa hukum materiil akan lumpuh karena tidak tahu yang akan dijelmakannya, sebaliknya peradilan tanpa hukum acara akan liar sebab tidak ada batas-batas yang jelas dalam melakukan wewenangnya ${ }^{9}$.

Hukum acara sebagai hukum formal, didalamnya juga mengandung unsur materiil maupun formal. Unsur materiil hukum acara dalam hukum (Belanda) disebut " actienrecht " ( substantive law of procedure), merupakan ketentuan yang mengatur hubungan hukum yang terjadi karena beracara. Unsur formal hukum acara mengatur tentang cara yang harus diperhatikan dalam beracara, yaitu mengatur tentang cara menggunakan wewenang seperti ditentukan dalam unsur materiil ${ }^{10}$.

Upaya hukum yang diberikan keempat pengadilan tersebut terdapat kesamaan yaitu upaya hukum tingkat pertama, upaya hukum Banding, Kasasi serta upaya hukum luar biasa Peninjauan Kembali.

Selain ke-empat lingkungan peradilan di atas, di dalam ke - empat lingkungan peradilan tersebut masih dapat dibentuk badan-badan peradilan khusus berdasarkan undang-undang, hal demikian dijelaskan dalam Pasal 27 UU.Kekuasaan Kehakiman yang menyatakan,

“ Pengadilan khusus hanya dapat dibentuk dalam salah satu lingkungan peradilan yang berada dalam salah satu lingkungan peradilan yang berada di bawah MA sebagaimana yang dimaksud dalam Pasal 25 “.

Berbicara mengenai kriteria kekhususan dari sebuah Pengadilan, Paulus Effendie Lotulung berpendapat bahwa, sifat khusus, itu bisa didasarkan pada kewenangan mengadili ( kompetensi ) yang khusus, jenis-jenis perkara, hukum acara atau proses perkara yang bersifat khusus ${ }^{11}$.

Pada tanggal 12 April 2002, lahir peradilan baru menambah jumlah peradilan yang ada di Indonesia, yaitu Pengadilan Pajak. Pengadilan Pajak dibentuk berdasarkan Undang-undang. No.14 Tahun 2002 ( selanjutnya disebut UU.No.14 Tahun 2002 ), dalam Lembaran Negara Tahun 2002 Nomor 27 tentang Pengadilan Pajak. Pengadilan Pajak adalah badan peradilan yang melaksanakan kekuasaan kehakiman bagi wajib pajak atau penanggung pajak yang mencari keadilan terhadap sengketa pajak. Pengadilan Pajak

\footnotetext{
${ }^{8}$ Sudikno Mertokusumo, Bunga rampai Ilmu Hukum, Liberty, Yogyakarta, 1984, hlm. 201.

${ }^{9}$ Sjahran Basah, Tolok Ukur..., Op.Cit., hlm. 31.

${ }^{10}$ Ibid, hlm. 82

${ }^{11}$ Paulus Effendie Lotulung, Wewenang Pengadilan Dalam Penanganan Sengketa Pajak, Berita Pajak
} No. 1410 / Tahun XXXII, Januari 2000, hlm. 41-42 
hanya ada satu yang terletak di ibukota Negara. Pembinaan teknis peradilan bagi Pengadilan Pajak dilakukan oleh Mahkamah Agung, sedangkan pembinaan organisasi, administrasi, dan keuangan bagi Pengadilan Pajak dilakukan oleh Departemen Keuangan.

Lahirnya Undang-undang No.4 tahun 2004 tentang Kekuasaan Kehakiman sebelum keluarnya UU 48 tahun 2009 khususnya dalam penjelasan Pasal 15 memberi penjelasan bahwa Pengadilan Pajak merupakan contoh pengadilan khusus yang masuk pada lingkungan Peradilan Tata Usaha Negara. Hal tersebut ditegaskan lagi dalam beberapa undang-undang antara lain UU No 28 tahun 2007 tentang Ketentuan Umum Tata Cara Perpajakan, UU 48 tahun 2009 tentang Kekuasaan Kehakiman dan UU 51 tahun 2009 tentang PTUN.

Sebagai suatu badan peradilan, Pengadilan Pajak mempunyai kekuasaan yang dapat diuraikan sebagai berikut: 1.Pengadilan Pajak mempunyai tugas memeriksa, memutus sengketa pajak. 2.Pengadilan pajak dalam tingkat Banding hanya memeriksa dan memutus sengketa atas keputusan keberatan, kecuali ditentukan lain oleh peraturan perundang-undangan yang berlaku.3.Dalam hal gugatan, Pengadilan Pajak memeriksa dan memutus sengketa atas pelaksanan penagihan pajak atau keputusan pembetulan atau keputusan lainnya sebagaimana dimaksud dalam Pasal 23 ayat ( 2 ) Undang-undang Nomor 6 Tahun 1983 sebagaimana beberapa kali diubah terakhir dengan Undang-undang nomor 16 tahun 2009.

Pengadilan Pajak merupakan Pengadilan tingkat pertama dan terakhir dalam memeriksa dan memutus sengketa pajak. Sebagaimana hukum acara yang lainnya, dalam hukum acara Pengadilan Pajak juga terlihat mekanisme penyelesaian sengketa pajak. Dalam hukum acara tersebut secara implisit tersirat bahwa penyelesaian sengketa pajak mengenal adanya upaya administratif, yaitu upaya keberatan. Sengketa pajak yang dapat diselesaikan melalui upaya keberatan adalah sengketa yang yang terjadi karena adanya ketidak setujuan wajib pajak atas SKP dan atas pemotongan dan pemungutan oleh pihak ketiga berdasarkan ketentuan undang-undang.

Apabila wajib pajak merasa dirugikan atas SKP yang dikeluarkan fiskus, atau atas pemotongan atau pemungutan oleh pihak ketiga maka berhak untuk mengajukan keberatan kepada pejabat yang mengeluarkan SKP tersebut. Untuk Pajak Pusat surat keberatan diajukan ke Direktur Jenderal Pajak melalui Kantor Pelayanan Pajak setempat. Untuk Pajak Daerah surat keberatan diajukan ke Kepala Daerah ( Untuk Pajak Propinsi 
Keberatan diajukan kepada Gubernur dan untuk Pajak Kabupaten / Kota surat keberatan diajukan kepada Bupati atau Kepala Pemerintah Kota ), melalui Kepala Dinas Pendapatan Daerah masing-masing.Tata cara pengajuan keberatan untuk Pajak Pusat diatur dalam UU KUP dan untuk Pajak Daerah diatur dalam UU No.28 tahun 2009 tentang Pajak Daerah.

Terhadap putusan fiskus, apabila wajib pajak tidak menerima hasil keputusan keberatan maka wajib pajak dapat melakukan banding ke Pengadilan Pajak, dengan keharusan memenuhi syarat-syarat tertentu. Apabila dilihat dari peristilahan, istilah banding dalam sistem peradilan secara umum, banding adalah upaya lanjutan dari peradilan tingkat I. Sementara istilah "banding” dalam penyelesaian sengketa pajak adalah upaya lanjutan dari upaya keberatan yang notabene adalah upaya administratif, hal ini tentunya agak membingungkan apakah yang dimaksud istilah banding tersebut apakah banding administratif atau banding murni.

Sebagaimana diketahui upaya aministratif dalam sengketa administrasi dikenal adanya upaya keberatan dan apabila tidak puas dapat mengajutan upaya administratif lanjutan yaitu banding administratif. Upaya administartif yang berupa keberatan maupun banding administratif dapat salah satu yang ditawarkan maupun dua-duanya. Apabila upaya administratif yang ditawarkan sudah selesai dan justiabelen masih tidak puas dan ingin mencari upaya hukum lanjutan maka menurut Pasal 48 dan Pasal 51 ayat (3) UU PTUN, dapat mengajukan upaya gugatan ke Pengadilan Tinggi Tata Usaha Negara. Hal demikian dalam UU No.30 tahun 2014 tentang Administrasi Pemerintahan khususnya Pasal 76 ayat (3) yang pada intinya menyatakan bahwa dalam hal warga masyarakat tidak menerima keputusan upaya administratif maka dapat mengajukan gugatan ke Pengadilan.

Selain sengketa atas suatu keputusan keberatan ( putusan keberatan adalah putusan atas keberatan diajukan oleh wajib pajak akibat adanya SKP ), sengketa antara wajib pajak dengan fiskus dapat terjadi akibat adanya pelaksanaan penagihan pajak, dan sebagai akibat adanya keputusan-keputusan lain yang dikeluarkan oleh fiskus antara lain Keputusan Pembetulan yang berkaitan dengan STP, Keputusan Pengurangan atau Penghapusan Sanksi Administrasi, Keputusan Pengurangan atau Pembatalan Surat Ketetapan, dan Keputusan yang berkaitan dengan pelaksanaan keputusan perpajakan lainnya, misalnya Keputusan Pengembalian Pendahuluan Kelebihan Pajak . "Sengketa yang terjadi sebagai akibat adanya keputusan-keputusan lain yang dikeluarkan fiskus “ di atas adalah sengketa atas keputusan-keputusan perpajakan yang merupakan keputusan bebas yang dikeluarkan oleh fiskus. Keputusan bebas adalah keputusan timbul sebagai 
konsekuensi diberikannya kebebasan bertindak ( freis ermessen ) yang diberikan kepada pejabat administrasi negara ( fiskus ).

Terhadap pelaksanaan Surat Paksa, Surat Perintah Melaksanakan Penyitaan, atau Pengumuman Lelang dan Keputusan-keputusan yang dikeluarkan fiskus sebagaimana penulis uraikan diatas wajib pajak berhak untuk mengajukan gugatan ke Pengadilan Pajak disertai dengan syarat-syarat yang ditentukan oleh undang-undang. Sesuai tugas dan wewenang Pengadilan Pajak, Pengadilan berwenang memeriksa dan memutus sengketa pajak yang terjadi karena adanya pengajuan banding dan gugatan tersebut. Pengaturan mekanisme penyelesaian sengketa pajak melalui Pengadilan Pajak diatur dalam hukum acara yang secara tegas dimuat dalam Pasal 34 s/d Pasal 88 UU No.14 tahun 2002.

Apabila dibandingkan dengan sistem peradilan secara umum, mekanisme penyelesaian sengketa pajak hampir sama dengan mekanisme penyelesaian sengketa administrasi dalam PERATUN, salah satu kesamaannya adalah dalam UU yang mengatur PERATUN juga dikenal adanya upaya administratif. Keberadaan upaya administrasi menurut Hukum Administrasi negara memang diakui keberadaannya sebagai penyelesai sengketa administrasi.

Meskipun ada persaman dengan PERATUN, tetapi ada beberapa hal juga yang membedakan antara mekanisme penyelesaian sengketa pajak dengan mekanisme penyelesaian sengketa dalam PERATUN dan bahkan dengan peradilan pada umumnya yaitu dalam penyelesaian sengketa pajak tidak mengenal upaya hukum Kasasi dan hanya mengenal upaya hukum luar biasa yaitu Peninjauan Kembali. Tidak dikenalnya upaya hukum Kasasi pada dasarnya tidak sejalan dengan ketentuan peradilan pada umumnya, khususnya Pasal 23 UU Kekuasaan Kehakiman, yang menyatakan, “ Atas putusan Pengadilan dalam tingkat banding dapat dimintakan Kasasi kepada Mahkamah Agung....". Selain itu, perbedaan lain juga terlihat bahwa jumlah Pengadilan yang hanya satu sementara dalam sistem peradilan yang lain mengenal upaya hukum tingkat pertama yang berada di tingkat Kabupaten/Kota, upaya banding di Pengadilan Tinggi yang berada ditingkat Provinsi.

Hal lain yang membedakan dengan peradilan lainnya adalah terkait pembinaan Peradilan. Pembinaan teknis Pengadilan Pajak dilakukan oleh MA sementara pembinaan organisasi, administrasi, dan keuangan bagi Pengadilan Pajak yang masih dilakukan oleh Departemen Keuangan. Sementara dalam peradilan lainnya seluruh pembinaan baik itu teknis, organisasi, administrasi dan keuangan di bawah MA. 


\section{Simpulan}

Sengketa pajak di Indonesia, khususnya sengketa atas Surat Ketetapan Pajak dapat diselesaikan melalui upaya penyelesaian sengketa dalam ranahnya eksekutif terlebih dahulu yaitu upaya keberatan yang merupakan salah satu bentuk penyelesaian sengketa melalui upaya administratif, dan penyelesaian sengketa melalui lembaga peradilan murni (yudikatif) yaitu Pengadilan Pajak yang berupa upaya hukum banding dan gugatan. Penyelesaian sengketa pajak tidak mengenal upaya hukum Kasasi tetapi mengenal upaya hukum Peninjaun Kembali.

Mekanisme Penyelesaian sengketa pajak apabila dilihat dengan sistem peradilan secara umum terlihat bahwa ada suatu kekhususan tersendiri yang berbeda dengan sistem penyelesaian sengketa pada peradilan yang lainnya. Ada beberapa hal yang kurang sesuai apabila dikaitkan dengan sistem penyelenggaraan peradilan lainnya, hal demikian dapat terlihat dari upaya hukum yang ditawarkan maupun terkait dengan jumlah peradilannya di Indonesia. Untuk lebih menjamin perlindungan hukum khususnya terhadap wajib pajak perlu dilakukan pembenahan baik terkait kelembagaan maupun mekanisme penyelesaian sengketanya yang diselaraskan dengan sistem peradilan secara umum.

\section{Daftar Pustaka}

Rochmat Soemitro, 1992, Pengantar Singkat Hukum Pajak,Eresco, Bandung , 1991,Asas Dan Dasar Perpajakan Jilid 2, Eresco, Bandung. ,Asas Dan Dasar Perpajakan jilid 3.Eresco,Bandung,1997.

Sudikno Mertokusumo, Bunga rampai Ilmu Hukum, Liberty, Yogyakarta, 1984.

Sjahran Basah, Eksistensi Dan Tolok Ukur Badan Peradilan Administrasi di Indonesiat, Bandung, 1989

Paulus Effendie Lotulung, Wewenang Pengadilan Dalam Penanganan Sengketa Pajak, Berita Pajak No. 1410 / Tahun XXXII, Januari 2000, hlm. 41-42 